\title{
Hubungan Tingkat Kecemasan Dengan Performa Atlet Tim Bolabasket Putra Kota Surabaya Dalam Persiapan Pekan Olahraga Provinsi IV di Kota Madiun
}

\section{Himawan Wismanadi ${ }^{a}$}

${ }^{a}$ Fakultas Ilmu Keolahragaan, Universitas Negeri Surabaya, Surabaya, Indonesia

*Corresponding author: wismanadi@yahoo.co.id

\section{A R T I CLE INFO}

Article history:

Received 15 April 2017

Received in revised form 23 April 2017

Accepted 29 April 2017

\section{Keywords:}

Kecemasan, Perfoma Bolabasket

\begin{abstract}
A B S T R A C T
Psikologi olahraga diamalkan untuk membantu atlet agar dapat memperlihatkan prestasi puncak, dan bagi atlet berbakat agar bakatnya bisa dikembangkan sebaik-baiknya tanpa hambatan dari faktor-faktor yang ada dalam kepribadiannya. Penampilan atlet dalam kompetisi sehingga mencapai prestasi yang optimal merupakan perpaduan berbagai faktor, diantaranya faktor fisik, keterampilan motorik, teknik dan latihan. Disamping itu faktor psikologis seperti kepribadian, motivasi, percaya diri (The Confidence), merupakan faktor-faktor penting yang perlu diperhatikan oleh pelatih maupun guru pendidikan jasmani. Jenis penelitian yang digunakan yaitu penelitian korelasional dengan pendekatan deskriptif kuantitatif. Korelasional adalah suatu penelitian yang menghubungkan satu atau lebih variabel bebas dengan variabel terikat tanpa ada upaya untuk mempengaruhi variabel tersebut. (Arikunto, 2013: 121). Subjek dalam penelitian ini adalah sejumlah 10 atlet yang tergabung dalam tim bolabasket kota Surabaya yang disiapkan mengikuti kejuaraan Porprov ke IV di kota Madiun. Hasil penelitian ini menggunakan angket tes kecemasan dan angket tes performa atlet. Pengambilan data tingkat kecemasan menggunakan angket tes kecemasan, sedangkan data performa atlet menggunakan tes performa atlet. Nilai tes kecemasan hasil pengolahan dengan menggunakan SPSS Versi 22, maka rata-rata hasil tes kecemasan sebesar 48,3 dan hasil tes performa atlet pengolahan rata-rata sebesar 164.5. Uji normalitas berdistribusi normal. sebesar 0.200 lebih besar dari 0.05 . uji korelasinya sebesar -0.563 atau $32 \%$, dengan kategori cukup. Kesimpulan yang diperoleh dari hasil penelitian ini adalah ada hubungan antara kecemasan dengan penampilan (performa) atlet bolabasket pada tim putra kota Surabaya. Sedangkan besarnya hubungan kecemasan dengan penampilan (performa) atlet bolabasket pada tim putra kota Surabaya sebesar $32 \%$
\end{abstract}

\section{Pendahuluan}

Penampilan atlet dalam kompetisi sehingga mencapai prestasi yang optimal merupakan perpaduan berbagai faktor, diantaranya faktor fisik, keterampilan motorik, teknik dan latihan. Disamping itu faktor psikologis seperti kepribadian, motivasi, percaya diri (The Confidence), merupakan faktor-faktor penting yang perlu diperhatikan oleh pelatih maupun guru pendidikan jasmani.

Psikologi olahraga diamalkan untuk membantu mencetak atlet agar dapat memperlihatkan prestasi puncak, dan bagi atlet berbakat agar bakatnya bisa dikembangkan sebaik-baiknya tanpa hambatan dari faktorfaktor yang ada dalam kepribadiannya.

Menurut Gunarsa (2004:65) bahwa kecemasan dapat berpengaruh pada kondisi fisik maupun mental atlet yang bersangkutan seperti denyut jantung meningkat, telapak tangan berkeringat, mulut kering yang menimbulkan rasa haus, gangguan-gangguan pada perut atau lambung dan Otot-otot pundak dan leher menjadi kaku.

Dalam persiapan pelaksanaan PORPROV IV-2013 Jawa Timur, tim bolabasket putra Kota Surabaya berusaha melakukan persiapan-persiapan, aktivias yang dilakukan sejak selesainya porprov ke III di Kota Kediri. Pesiapan-persiapan ini dilakukan untuk dapat mempertahankan juara, untuk itu segala sesuatu yang berhubungan dengan usaha untuk mempertahan sebagai juara bertahan peneliti bekerjasama dengan KONI Surabaya dan Perbasi Kota Surabaya melakukan penelitian yang berjudul Hubungan Tingkat Kecemasan dengan Performa Atlat Tim Bolabasket Putra Kota Surabaya.

\section{Metode}

Jenis penelitian yang digunakan yaitu penelitian korelasional dengan pendekatan deskriptif kuantitatif. Korelasional adalah suatu penelitian yang menghubungkan satu atau lebih variabel bebas dengan variabel terikat tanpa ada upaya untuk mempengaruhi variabel tersebut. (Arikunto, 2013: 121). Subjek dalam penelitian ini adalah sejumlah 10 atlet yang tergabung dalam tim bolabasket putra kota Surabaya yang disiapkan mengikuti kejuaraan Porprov ke IV di Madiun.

\section{Hasil dan Diskusi}

\section{Hasil}

Pengambilan data dalam penelitian ini menggunakan angket tes kecemasan dan angket tes performa atlet. Pengambilan data tingkat kecemasan (X) menggunakan angket tes kecemasan, sedangkan data performa atlet $(\mathrm{Y})$ menggunakan angket tes performa atlet yang dilakukan oleh tim putra bolabasket kota Surabaya..

Berdasarkan perngolahan dengan menggunakan SPSS Versi 22, maka rata-rata hasil tes kecemasan sebesar 48.3000 dan hasil tes performa atlet pengolahan rata-rata sebesar 164.5000 .

Berdasarkan pengolahan nilai probabilitas atau $p$ Kolmogorov Smirnov (K-S) pada variabel kecemasan dan performa atlet lebih besar dari 0.05 , maka dengan demikian dapat dinyatakan bahwa semua data dari semua variabel penelitian dengan subjek berjumlah 10 orang tersebut 
berdistribusi normal.

Untuk mengetahui seberapa besar hubungan kecemasan dengan performa atlet tim putra bolabasket kota Surabaya maka terlebih dahulu akan dihitung korelasi antara kedua variabel tersebut dengan menggunakan SPSS versi 20, adapun hasilnya nilai korelasinya sebesar 0.563 , setelah nilai korelasinya dibandingkan dengan sig. (2-talled) sebesar 0.090. Karena nilai korelasinya lebih besar dari sig. (2-talled) maka dapat dikatakan ada korelasi antara tingkat kecemasan dengn performa atlet

\section{Pembahasan}

Berdasarkan analisis data yang diolah dengn SPSS versi 20, diketahui bahwa pengaruh tingkat kecemasan terhadap performa artlet sebesar -0.563 atau $32 \%$, sedangkan sisanya dapat dipengaruhi oleh faktor lain. Rendahnya hasil yang keterkaitan hubungan antar ke dua variabel tersebut disebabkan tidak bisanya atlet mengeluarkan kemampuannya secara maksimal. Menurut Gunarsa (2004:66) saat mengalami kecemasan otot-otot menjadi tegang pada beberapa bagian tubuh yang bisa menyebabkan atlet kehilangan koordinasi, sehingga dapat menurunkan keterampilan (skill). Apabila atlet dapat mengendalikan perasaan cemas ketika bertanding maka performanya juga akan optimal.

Berdasarkan analisis tersebut diketahui bahwa dengan tanda (-) menunjukkan hubungan yang berlawanan arah, yaitu jika tingkat kecemasan tinggi maka akan mengakibatkan ketepatan performa atlet atau penmpilamnya menjadi rendah. Sedangkan nilai korelasi sebesar 0,563 tersebut termasuk dalam kategori korelasi yang cukup. Menurut Siregar (2014: 337) bahwa tingkat korelasi dan kekuatan hubungan di bagi menjadi 5 yaitu: 1) Sangat lemah skor antara 0,00-0,199, 2). Lemah skor antara 0,20-0,399, 3). Cukup dengan skor antara 0,40-0,599,4). Kuat skor antar 0,60-0,799 dan 5). Sangat kuat dengan skor antara 0,80 0,100 .

Kecemasan dalam pertandingan akan menimbulkan tekanan emosi yang berlebih, sehingga konsentrasi atlet untuk menghadapi lawan akan berkurang. Hal ini berarti kinerja dari atlet tersebut menurun, maka kecermatan juga akan menurun dan menyebabkan prestasi dari atlet menurun. Karena ketika bertanding, aspek yang sangat menentukan adalah mental atau psikologis atlet. Kondisi fisik, teknik, dan taktik sudah dipersiapkan jauh saat sebelum pertandingan, namun semua itu akan siasia jika atlet tidak dapat mengendalikan kecemasannya

\section{Simpulan dan Saran}

Simpulan yang diperoleh dari hasil penelitian ini adalah ada hubungan antara kecemasan dengan penampilan (performa) atlet bolabasket pada tim putra kota Surabaya dalam menghadapi Pekan Olaharaga Provinsi Jawa Timur di Kota Madiun dalam kondisi siap tetapi perlu mendapat perhatian pelatih agar tidak menimbulkan persoalan disaat pertandingan. Sedangkan besarnya hubungan kecemasan dengan penampilan (performa) atlet bolabasket pada tim putra kota Surabaya sebesar 32\% dengan kategori cukup.

Berdasarkan hasil penelitian dan simpulan di atas, maka saran yang dapat peneliti sampaikan adalah sebagai berikut: (1) Pemain diharapkan dapat mengendalikan perasaan cemas ketika bertanding agar tidak mengganggu performannya di lapangan. (2) Pelatih seharusnya memperhatikan kecemasan para pemain, dengan sering melakukan latihan simulasi (sparing partner) dengan berbagai macam lawan, agar pemain terbiasa dengan situasi yang dapat menimbulkan rasa cemas. (3) Penelitian masih jauh dari sempurna, hal ini disebabkan banya faktor yang belum peneliti lakukan. Untuk itu penelitian bisa dikembankan ke arah yang lebih baik

\section{Daftar Rujukan}

Amir, N. 2012. "Pengembangan Alat Ukur Kecemasan Olahraga". (Online), Vol 16, Nomor 1, (http://download.portalgaruda.org/article.php?article $=52273 \& \mathrm{val}=4$ 48, diunduh 15 November 2015)

Andianta. 2014. "Perbedaan Pengaruh Tingkat Kesulitan Dan Tinggi Badan Terhadap Hasil Tembakan Free Throw Bolabasket”. (Online), $\quad$ Vol $\quad 1, \quad$ Nomor 1 , (Http://Jurnal.Pasca.Uns.Ac.Id/Index.Php/Ss/Article/View/1812, diunduh 15 November 2015).

Arikunto, S. 2013. Prosedur Penelitian. Jakarta: Unik Ciptu.

Barth Katrin \& Boesing Lothar , 2009. Learning Basketball. by Meyer \& Meyer Sport (UK) Ltd.

Burrall Paye, Patrick Paye. 2013 Youth basketball drills 2nd ed. by Human Kinetics, Inc. the United States of America

Candy, W. 2013. Pengaruh Bentuk Latihan Untuk Mengurangi Kecemasan Terhadap Hasil Free Throw (Tembakan Bebas) Cabang Olahraga Bolabasket Pada Atlet SMA Negeri 9 Bandung. (Online). Vol 1, Nomor $\quad 3, \quad$ (Http://PkrIkor.Upi.Edu/Artike1/391@\%20WAWAN\%20CANDY. Pdf, diunduh 15 November 2015).

Donovan M , 2010, Youth Basketball 101 drills. A \& C Black Publishers Ltd London.

Gunarsa, Singgih. 2004. Psikologi Olahraga Prestasi. Jakarta: PT BPK Gunung Mulia.

Harsono. 1988. Choaching Dan Aspek-Aspek Psikologi Dalam Coaching. Jakarta: Cv Tambak Kusuma.

Kosasih, Danny. 2009. Fundanmental Basketball. Semarang: Karmedia.

Krause, J, D Meyer, Dan Jerry Meyer.2008. Basketball Skills And Drills. United States: Human Kinetics.

Meyer, Don. Meyer, Jerry. Basketball Coaching, Basketball skills and drills. by Human Kinetics, Inc. United States of America

Oliver, J. 2003. Dasar-Dasar Bolabasket. Bandung: Pakar Raya.

PB Perbasi. 1990 Pedoman Pelatih Bolabasket Modern . Perbasi Jakarta.

PB Perbasi 2004. Metode Pelatihan Dasar. Perbasi Jakarta.

Siregar, Syofian. 2014. Statistik Parametrik Untuk Penelitian Kuantitatif. Jakarta: Remaja Rosdakarya.

Subhabrata. 2013. "Measurement Of Competition Level Anxiety Of Collage Level Athletes By Using SCAT". (Online), (http://www.ijesit.com/Volume\%202/Issue\%203/IJESIT201303_53 .pdf), diunduh 15 november 2015.

Sugiyono. 2013.Metode Penelitian Kuantitatif Dan Kualitatif. Bandung: CV. Alfabeta.

Sugiyono. 2013. Statistika Untuk Penelitian.Bandung: CV. Alfabeta.

Wismanadi H. 2014 Handout Bolabasket. Untuk Kalangan Sendiri. FIKUnesa

Wissel Hal. (1996). Bola Basket Dilengkapi dengan Program Pemahiran Teknik dan Taktik. Jakarta: PT Raja Grafindo Persada.

Wissel Hal .1996. Steps to Success for Basketball, diterjemahkan oleh Bagus Pribadi. . Bola Basket Panduan Lengkap Latihan Khusus Pemantapan. Jakarta: PT Raja Grafindo Persada.

Wissel Hal . 2012. Steps to Success for Basketball, by Human Kinetics, Inc. United States of America 
JOURNAL OF SPORT SCIENCE AND EDUCATION (JOSSAE) VOL: 2, NO: 1 APRIL (2017) Journal homepage: http://journal.unesa.ac.id/index.php/jossae/index 